\title{
Contributions to the Andean Senecioneae (Compositae), part IV: Three new records for the flora of Bolivia
}

\author{
Joel CALVO ${ }^{1, *} \&$ Modesto ZÁRATE ${ }^{2}$ \\ ${ }^{1}$ Instituto de Geografía, Facultad de Ciencias del Mar y Geografía, Pontificia Universidad Católica de Valparaíso, \\ Av. Brasil 2241, 2362807 Valparaíso, Chile. \\ ${ }^{2}$ Herbario Forestal Nacional Martín Cárdenas, Centro de Biodiversidad y Genética de la Universidad Mayor de San Simón, \\ Parque la Torre, casilla 538, 2500 Cochabamba, Bolivia. \\ "Corresponding author: calvocasas@gmail.com, https://orcid.org/0000-0003-2340-7666 \\ ${ }^{2}$ zarate moo@yahoo.es, https://orcid.org/0000-0001-8842-9351
}

\begin{abstract}
Three new species belonging to the tribe Senecioneae Cass. are recorded for the first time in Bolivia: Senecio jujuyensis Cabrera, Senecio moqueguensis Montesinos, and Werneria microphylla H.Beltrán \& S.Leiva. Taxonomic discussions and distribution notes are provided for each species, as well as illustrations when available.
\end{abstract}

Keywords. Andes, Asteraceae, taxonomy.
Resumen. Tres nuevas especies pertenecientes a la tribu Senecioneae Cass. se citan por primera vez en Bolivia: Senecio jujuyensis Cabrera, Senecio moqueguensis Montesinos y Werneria microphylla H.Beltrán \& S.Leiva. Se presenta una discusión taxonómica y notas de distribución para cada una de las especies, así como ilustraciones cuando ha sido posible.

Palabras clave. Andes, Asteraceae, taxonomía.

How to cite this article: Calvo J. \& Zárate M. 2019. Contributions to the Andean Senecioneae (Compositae), part IV: Three new records for the flora of Bolivia. Anales del Jardin Botánico de Madrid 76 (2): e089. https://doi.org/10.3989/ajbm.2528

Title in Spanish: Contribución a las Senecioneae andinas (Compositae), parte IV: tres nuevas citas para la flora de Bolivia.

Received: 31-V-2019; accepted: xx-xx-2019; published on-line: 20-XI-2019; Associate Editor: A. Quintanar.

\section{INTRODUCTION}

The Andes of South America are a noteworthy center of generic diversity and speciation of the tribe Senecioneae Cass. (Compositae Giseke) (Nordenstam \& al. 2009). In Bolivia this tribe is represented by 14 genera, excluding Culcitium Bonpl. and Lasiocephalus Willd. ex Schltdl., that are widely accepted as a part of Senecio L. (Pelser \& al. 2007; Calvo \& Freire 2016; Salomón \& al. 2018). It is mainly distributed along the mid- and highlands in the ecosystems of the puna grassland and the Yungas (montane and cloud forests).

On-going studies of this tribe in the Andes have led us to record three new species for Bolivia: Senecio jujuyensis Cabrera, Senecio moqueguensis Montesinos, and Werneria microphylla H.Beltrán \& S.Leiva. According to Jørgensen \& al. (2014), Senecio is the seventh largest genus of the Bolivian vascular flora embracing c. 99 species. A recent contribution elevated this number to c. 103 (Calvo \& Fuentes 2018). On the other hand, the genus Werneria Kunth is represented by 18 species (Calvo \& al., unpublished).

\section{MATERIAL AND METHODS}

This contribution is the result of an intensive review of the published bibliography, field work, and the revision of specimens kept at BOLV, LPB, MA, and USM. Additionally, photographs of specimens from other institutions were studied: LP, MO, and US; herbarium acronyms follow Thiers (2019). The bibliographic revision was mainly based on Beck \& Ibáñez (2014), Freire \& al. (2014), Jørgensen (2014), and Tropicos.org (2019). The field work was conducted during February 2019, mainly through the Bolivian departments of Oruro and Potosí.

\section{RESULTS AND DISCUSSION}

Senecio jujuyensis Cabrera, Bol. Soc. Argent. Bot. 11: 49, 50 Fig. 3 (Cabrera 1966). Original citation: “Jujuy: Dep. Humahuaca, Mina Aguilar.”. Type: [Argentina] Jujuy, Humahuaca, mina Aguilar, $4200 \mathrm{~m}$ a.s.1., 23 Feb. 1963, A.L. Cabrera \& al. 15471 leg. (holo-: LP 000536 photo!). Iconography: Cabrera (1966: Fig. 3); Fig. 1.

Distribution and habitat.-Argentina (Jujuy) and Bolivia (Potosí) (Fig. 2). All new records in Bolivia come from the province Sud Chichas. They grow in the dry 'puna' ecosystem at elevations of $3850-4050 \mathrm{~m}$ a.s.1. 


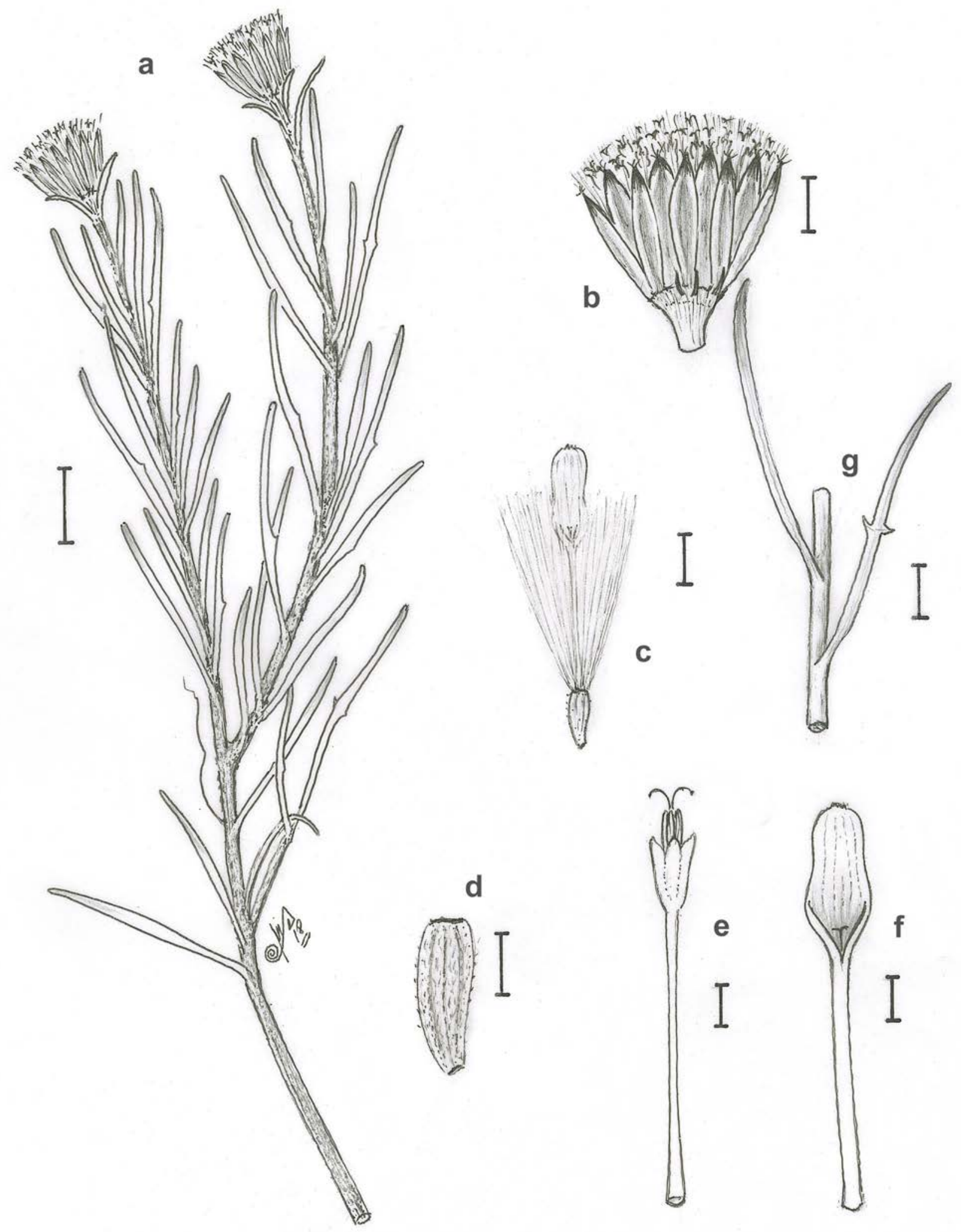

Fig. 1. Senecio jujuyensis Cabrera: a, habit; $\mathbf{b}$, involucre; $\mathbf{c}$, ray floret with achene; $\mathbf{d}$, achene without pappus; $\mathbf{e}$, disc floret; f, ray floret; g, leaves [S.G. Beck \& al. 33938 leg. (LPB); scales: $\mathrm{a}=1 \mathrm{~cm} ; \mathrm{b}, \mathrm{c}=2 \mathrm{~mm}$; d-f $=1 \mathrm{~mm} ; \mathrm{g}=5 \mathrm{~mm}$ ]. 
Discussion.-Until now, Senecio jujuyensis was considered endemic to Jujuy (Freire \& al. 2014). As pointed out by Cabrera (1966), this species is mainly characterized by its leaf polymorphism, especially concerning leaf margin. It varies from entire to remotely pectinate-pinnatisect, with 1-4 teeth per side. The capitulum has c. 14 short ray florets, sometimes reddish on the abaxial surface, and the involucre has 14-18 involucral bracts and bears 3-4 small supplementary bracts at the base.

Additional specimens examined-ARGENTINA. Jujuy: Moreno in fissuris rupium [El Moreno], 15 Dec. 1901, R.E. Fries 925 leg. (S). BOLIVIA. Potosí: Sud Chichas, Wakawañusca, al NO en línea recta de Salo aprox. 11.7 km, 6 Mar. 2012, S.G. Beck, F. Beck, and M. Giorgetta 33938 leg. (LPB); Sud Chichas, al SO en línea recta de la comunidad de Oploca aprox. 5.3 km, 27 Feb. 2012, F. Zenteno \& al. 11501 leg. (LPB); Sud Chichas, camino mirador Boris al $\mathrm{O}$ en línea recta de la ciudad de Tupiza aprox. 11 km, 4 Mar. 2012, F. Zenteno and L. Moya 11779 leg. (LPB); Sud Chichas, Wakawañusca, al NO en línea recta de Salo aprox. 11.3 km, 6 Mar. 2012, F. Zenteno and L. Moya 11868 leg. (LPB); Sud Chichas, arriba del mirador de Boris, al $\mathrm{O}$ en línea recta de la ciudad de Tupiza aprox. $14.7 \mathrm{~km}, 10$ Mar. 2012, F. Zenteno, L. Moya, and M. Giorgetta 11979 leg. (LPB); Sud Chichas, al OSO cruce a Nazanerito y Kucho aprox. 7.8 km, 10 Mar. 2012, F. Zenteno, L. Moya, and M. Giorgetta 11994 leg. (LPB); Sud Chichas, al OSO de Kucho en línea recta hacia Mojinete aprox. 4.4 km, 12 Mar. 2012, F. Zenteno, L. Moya, and M. Giorgetta 12087 leg. (LPB)

\section{Senecio moqueguensis Montesinos, PhytoKeys} 39: 3, 5 Fig. 1 (Montesinos-Tubée 2014). Original citation: "Moquegua Region, General Sánchez Cerro Province, Ubinas District, NW of Tassa (...) near Lake Pacosani.”. Type: Perú, Moquegua Region, General Sánchez Cerro Province, Ubinas District, NW of Tassa, near Lake Pacosani, 1606'43" S, 7044'45" W, 4653 m a.s.1., 3 Apr. 2009, D. Montesinos 2400 leg. (holo-: USM s.n.!). Iconography: Montesinos-Tubée (2014: Fig. 1); Fig. 3.

Distribution and habitat.-Bolivia (Oruro) and Peru (Arequipa, Moquegua, Tacna) (Fig. 2). The new record was found near Toro Mount, southeastern Oruro Department. It thrives in the subhumid 'puna' ecosystem, on exposed soils at elevations of 4600-4950 m a.s.l. Some other Compositae species growing in the same habitat are: Oriastrum stuebelii (Hieron.) A.M.R.Davies, Senecio humillimus Sch.Bip., Senecio puchei Phil., Werneria apiculata Sch. Bip., Werneria aretioides Wedd., Xenophyllum esquilachense (Cuatrec.) V.A.Funk, and Xenophyllum poposa (Phil.) V.A.Funk

Discussion.-This species belongs to the group of the discoid caespitose Senecio, more specifically to the subgroup displaying yellowish anthers, style-branches, and corollas. It is characterized by having spatulate leaves, distally shallowly dentate or crenate (with 3-5 teeth), and covered by pilose indumentum. A morphologically similar species is Senecio humillimus Sch. Bip, which has a wider distribution area (northern Argentina, Bolivia, northern Chile, and southern Peru). They differ by the leaf shape (linear vs. spatulate in Senecio moqueguensis), leaf margin (entire vs. distally shallowly dentate or crenate in Senecio moqueguensis), and leaf indumentum (glabrous vs. pilose in Senecio moqueguensis). Although such differences are readily noticeable on living plants, a detailed study under the stereo microscope is required on dry specimens because they are tiny plants. Its confusion with Senecio humillimus may explain that this species has been overlooked in Bolivia until now (see Jiménez \& al. 7988; LPB).

Concerning the type material of Senecio moqueguensis, it should be noted that the isotypes mentioned in the protologue do not clearly correspond to the same gathering than the holotype, although all of them are numbered "Montesinos 2400". The information about the locality reads "NW of
Tassa, near Lake Pacosani" on the holotype vs. "Yaretaj site, $4 \mathrm{~km} \mathrm{~W}$ of Coalaque locality near to Pacosani lake" on the isotypes. Likewise, the coordinates (" $16^{\circ} 06^{\prime} 43^{\prime \prime} \mathrm{S} 70^{\circ} 44^{\prime} 45^{\prime \prime} \mathrm{W}$ " on the holotype vs. " $16^{\circ} 06^{\prime} 50^{\prime \prime} \mathrm{S}$ $70^{\circ} 44^{\prime} 55^{\prime \prime} \mathrm{W}$ " on the isotypes) and the elevation (" $4653 \mathrm{~m}$ " on the holotype vs. " $4450 \mathrm{~m}$ " on the isotypes) also differ. According to ICN Art. 8.1 and 8.2 (Turland \& al. 2018), these specimens do not correspond to the same gathering because they do not come from the same locality as the labels show. On this basis, the isotypes designated by Montesinos-Tubée (2014) should be excluded from the type material. Herein, the collection corresponding to the isotypes is numbered Montesinos 2400bis in order to differentiate it from the holotype, i. e., Montesinos 2400.

Additional specimens examined.-BOLIVIA. Oruro: Eduardo Avaroa, Challapata, Livichuco, Tarpata, estribaciones del cerro Toro en el collado antes de las lagunas, 15 Feb. 2019, J. Calvo and M. Zárate 7879 leg. (BOLV); Challapata, Livichuco, Tarpata, parte baja de las estribaciones del cerro Toro, 15 Feb. 2019, J. Calvo and M. Zárate 7881 leg. (BOLV); Challapata, Livichuco, camino a cerro Toro, arriba de la laguna K'asiri, 29 Feb. 2016, I. Jiménez \& al. 7988 leg. (LPB). PERU. Arequipa: Caylloma, Vincocaya, 8 Apr. 1925, F.W. Pennell 13344 leg. (US). Moquegua: General Sánchez Cerro, pr. Tiriti, 10 Apr. 2005, C. Aedo and A. Galán de Mera 11263 leg. (MA n.v., USM); Ubinas, Yaretaj site, 4 km W of Coalaque locality near to Pacosani lake, 3 Apr. 2009, D. Montesinos 2400bis leg. (MO, USM); Ubinas, road east Pillone town, 24 Mar. 2013, D. Montesinos 4022 leg. (USM). Tacna: Tarata, laguna Casire [Casiri], 3 Apr. 1998, M.I. La Torre \& al. 2421 leg. (US, USM).

Werneria microphylla H.Beltrán \& S.Leiva, Phytotaxa 372: 297, 298 Fig. 1, 299 Fig. 2 (Beltrán \& Leiva 2018). Original citation: "Lima: prov. Huarochiri, distr. Chicla, Abra Anticona.”. Type: Peru, Lima, Huarochirí, Chicla,

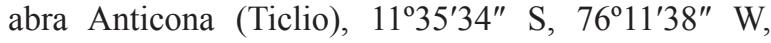
4877 m a.s.1., 29 Apr. 2017, H. Beltrán, S. Castillo, and

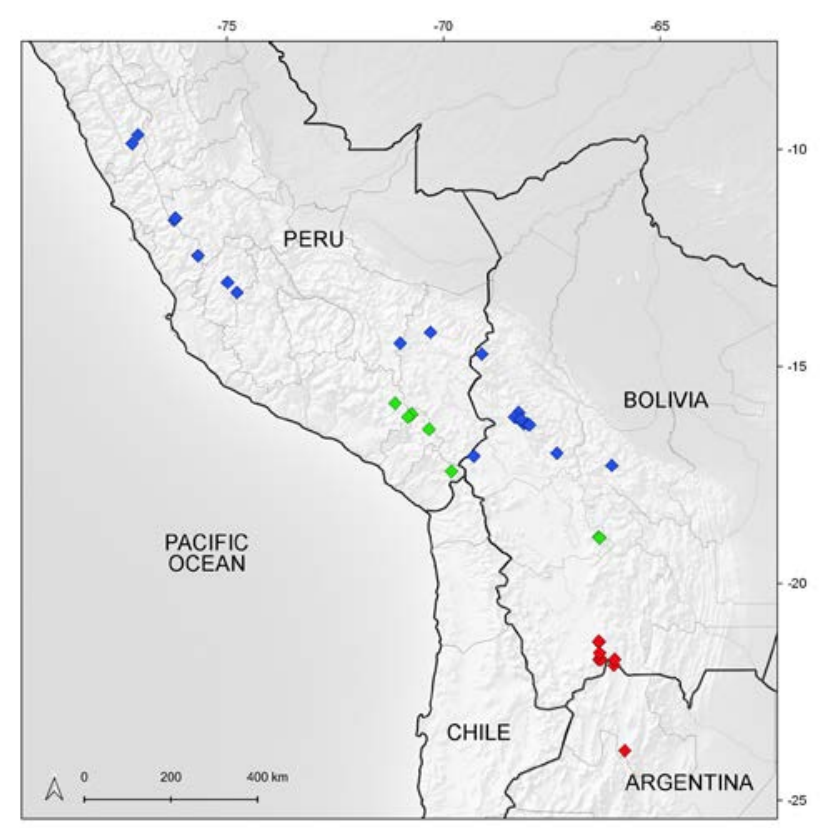

Fig. 2. Distribution map of Senecio jujuyensis Cabrera (red circles), Senecio moqueguensis Montesinos (green circles), and Werneria microphylla H.Beltrán \& S.Leiva (blue circles). The distribution of Senecio jujuyensis and Senecio moqueguensis is not based on a comprehensive revision. 
M. Arakaki 7970 leg. (holo-: USM 253391!; iso-: HAO n.v., HUSA n.v., HUT n.v.). Iconography: Beltrán \& Leiva (2018: Figs. 1 and 2).

Distribution and habitat.-Bolivia (Cochabamba, La Paz) and Peru (Ancash, Cusco, Huancavelica, Lima, Puno) (Fig. 2). It grows in Andean marshlands, known as 'bofedales', at elevations of 4100-5050 m a.s.l.

Discussion.-Werneria microphylla was recently described from Peru. We have found at the Bolivian herbaria several specimens of this species previously identified as Werneria pygmaea Gillies ex Hook. \& Arn. The leaf apex let anyone discriminate them from each other; Werneria microphylla has the apex aristate, while in Werneria pygmaea it is acute or obtuse. It should be noted that the length of the arista is quite variable and there are specimens displaying a rather apiculate apex, not clearly aristate. Other useful characters are the leaf lamina length $(2.5-5.7 \mathrm{~mm}$ vs. $7-80 \mathrm{~mm}$ in Werneria pygmaea) and the stem indumentum (glabrous or with scattered arachnoid trichomes vs. arachnoid-lanate in Werneria pygmaea).

Additional specimens examined-BOLIVIA. Cochabamba: cordillera del Tunari, por encima de la laguna de Huara-Huara, 17 Mar. 1990, G. Navarro 659 leg. (BOLV). La Paz: Murillo, valle de Zongo, aprox. $15 \mathrm{~km}$ desde la cumbre, 7 Apr. 1979, S.G. Beck 1274 leg. (LPB); Los Andes, del camino principal a Peñas, $43 \mathrm{~km}$ vía mina Fabulosa, laguna al pie del cerro Mullu Apacheta [Apachita], 18 Feb. 1980, S.G. Beck 2918 leg. (LPB); Murillo, Jacha Toloko, aprox. 21 km de la ciudad de La Paz, camino a Yungas, Mar. 1987, S. Estenssoro 34 leg. (LPB); Murillo, al pie del Illimani, junto a la mina El Águila, 25 Feb. 1979, J. Fernández Casas 2736 leg. (MA); Los Andes, an der Strabe zur Mine Fabulosa, westlich unterhalb der Pabhöhe, 10 Feb. 1980, T. Feuerer 8467b leg. (LPB); Franz Tamayo, área natural de manejo integrado Apolobamba, entre paso Sánchez y Carcapampa, por el camino entre Pelechuco y Carcapampa (Queara Nuevo), 24 Feb. 2008, A. Fuentes, I. Jiménez, and J. Quisbert 11977 leg. (LPB); Los Andes, Hichu-Kkota valley, $21 \mathrm{~km}$ from base of lgn. Khara Kkota along rd. to mina Fabulosa, near the pass, 25 Apr. 1995, V.A. Funk and C. González-Quint 11375 leg. (LPB); Los Andes, above cumbre (pass) on rd. through Hichu-Kkota valley on rd. to mina La Fabulosa, $21 \mathrm{~km}$ from base of lgn. Khara Kkota, 29 Apr. 1995, V.A. Funk 11409 leg. (LPB); Los Andes, above cumbre (pass) on rd. through Hichu-Kkota valley on rd. to mina La Fabulosa, $21 \mathrm{~km}$ from base of lgn. Khara Kkota, 29 Apr. 1995, V.A. Funk 11410 leg. (LPB); Los Andes, above cumbre (pass) on rd. through Hichu-Kkota valley on rd. to mina La Fabulosa, $21 \mathrm{~km}$ from base of lgn. Khara Kkota, crossroads of rd. to Tipuani and mina La Fabulosa, 29 Apr. 1995, V.A. Funk 11414 leg. (LPB); Murillo, de la cumbre hacia Kaluyo cerca del punto más alto, 10 Oct. 1986, E. García 881 leg. (LPB); Loayza, río Thia Kkota c. 4 km NW of Rodeo, c. 15 km N of Caxata, 5 Dec. 1987, M. Lewis 871250 leg. (LPB); Murillo, Milluni, a $18 \mathrm{~km}$ al NE de La Paz, 13 Jan. 1996, R.I. Meneses and J. Gonzáles 616 leg. (LPB); Omasuyos, Hichu Cota, después de la laguna Khara Khota, cerca al río Pauchintani, 14 Apr. 1985, M. Moraes 120 leg. (LPB); Los

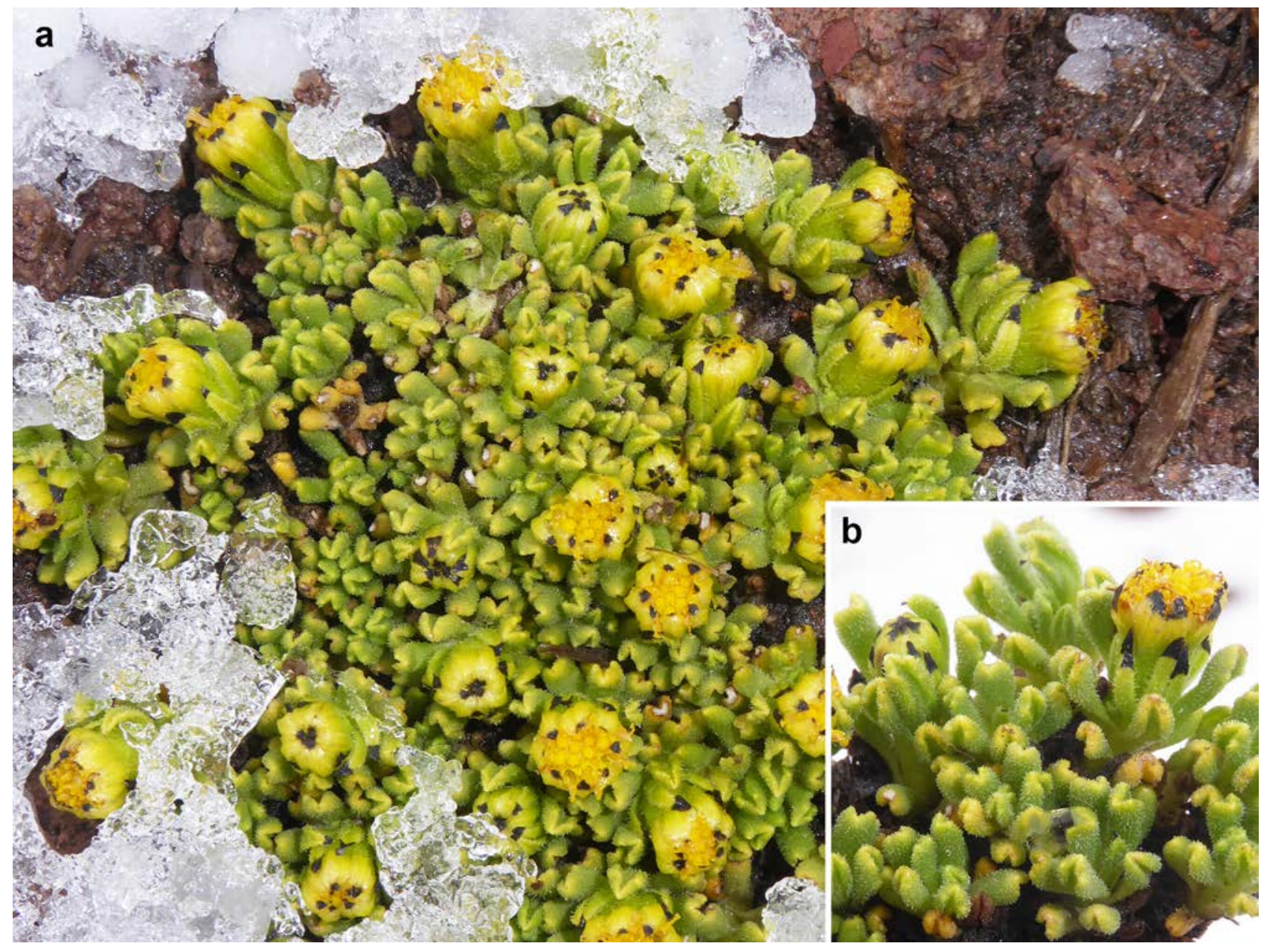

Fig. 3. Senecio moqueguensis Montesinos: a, habit; b, detail of the leaves [Pictures by J. Calvo at Toro Mount (Oruro, Bolivia)]. 
Andes, por encima de la represa del Tuni, 25 Mar. 2010, T. Ortuño and A.P. Sandoval 1020 leg. (LPB); Los Andes, por encima de la represa del Tuni, lugar conocido por los lugareños como "El Corral”, 26 Mar. 2010 T. Ortuño and A.P. Sandoval 1067 leg. (LPB); Los Andes, por encima de la represa del Tuni, lugar conocido por los lugareños como "El Corral", 26 Mar. 2010, T. Ortuño and A.P. Sandoval 1077 leg. (LPB); Los Andes, por encima de la represa del Tuni, lugar conocido por los lugareños como "El Corral", 26 Mar. 2010, T. Ortuño and A.P. Sandoval 1097 leg. (LPB); Los Andes, por encima de la represa Condoriri, cerca al glacial Condoriri, 27 Mar. 2010, T. Ortuño and A.P. Sandoval 994 leg. (LPB); Los Andes, valle de Hichu Kkota, 17 Nov. 1983, C. Ostria 10 leg. (LPB); Inquisivi, cumbre en el camino entre Quime y la carretera La Paz-Oruro, pasando $1 \mathrm{~km}$ al $\mathrm{N}$ por el camino hacia una mina, 13 Mar. 2003, J.R.I. Wood and T. Ortuño 19329 leg. (LPB).

\section{ACKNOWLEDGEMENTS}

We are grateful to the curators and staff of the herbaria mentioned in the text. Carlos Maldonado (LPB) is the author of the illustration of Senecio jujuyensis. This work has been funded by FONDECYT from Chile by means of a postdoctoral fellowship for the first author (project $\mathrm{N}^{\mathrm{o}} 3170270$ ).

\section{REFERENCES}

Beck S.G. \& Ibáñez D. 2014. Senecio L. In Jørgensen P.M., Nee M.H. \& Beck S.G. (eds.), Catálogo de las Plantas Vasculares de Bolivia. Monographs in Systematic Botany from the Missouri Botanical Garden 127: $281-287$.

Beltrán H. \& Leiva S. 2018. Werneria microphylla (Asteraceae, Senecioneae), a new species from the Andean marshes of Peru. Phytotaxa 372 (4): 296-300. https://doi.org/10.11646/phytotaxa.372.4.7

Cabrera A.L. 1966. Especies nuevas del género Senecio (Compositae) de la República Argentina. Boletín de la Sociedad Argentina de Botánica 11: 45-59.

Calvo J. \& Freire E. 2016. A nomenclator of Senecio group Lasiocephalus (Compositae, Senecioneae): nomenclatural and taxonomic notes and new typifications. Phytotaxa 260 (2): 116-130. http://dx.doi.org/10.11646/phytotaxa.260.2.2

Calvo J. \& Fuentes A.F. 2018. Three new caespitose species of Senecio (Senecioneae, Compositae) from Central Andes. Phytotaxa 375 (1): 70 80. https://doi.org/10.11646/phytotaxa.375.1.3
Freire S.E., Ariza Espinar L., Salomón L. \& Hernández M.P. 2014. Senecio L. In Zuloaga F.O. \& al. (eds.), Flora Argentina. Flora vascular de la República Argentina 7 (3): 27-220. Instituto de Botánica Darwinion, Buenos Aires.

Jørgensen P.M. 2014. Werneria Kunth. In Jørgensen P.M., Nee M.H. \& Beck S.G. (eds.), Catálogo de las Plantas Vasculares de Bolivia. Monographs in Systematic Botany from the Missouri Botanical Garden 127: 299-300.

Jørgensen P.M., Nee M.H. \& Beck S.G. 2014. Resultados. In Jørgensen P.M., Nee M.H. \& Beck S.G. (eds.), Catálogo de las Plantas Vasculares de Bolivia. Monographs in Systematic Botany from the Missouri Botanical Garden 127: 33-76.

Montesinos-Tubée D.B. 2014. Three new caespitose species of Senecio (Asteraceae, Senecioneae) from South Peru. PhytoKeys 39: 1-17. https://phytokeys.pensoft.net/articles.php?id=1541

Nordenstam B., Pelser P.B., Kadereit J.W. \& Watson L.E. 2009. Senecioneae. In Funk V.A., Susanna A., Stuessy T.F. \& Bayer R.J. (eds.), Systematics, Evolution, and Biogeography of Compositae: 503-525. International Association for Plant Taxonomy, Vienna.

Pelser P.B., Nordenstam B., Kadereit J.W. \& Watson L.E. 2007. An ITS phylogeny of tribe Senecioneae (Asteraceae) and a new delimitation of Senecio L. Taxon 56 (4): 1077-1104. http://dx.doi.org/10.2307/25065905

Salomón L., Sklenář P. \& Freire S.E. 2018. Synopsis of Senecio series Culcitium (Asteraceae: Senecioneae, Senecioninae) in the Andean region of South America. Phytotaxa 340 (1): 1-47. https://doi.org/10.11646/phytotaxa.340.1.1

Thiers B. 2019. Index Herbariorum: A global directory of public herbaria and associated staff. New York Botanical Garden's Virtual Herbarium, New York. Website: http://sweetgum.nybg.org/science/ih/ [accessed: 25 May 2019].

Tropicos.org. 2019. Tropicos.org. Missouri Botanical Garden, Saint Louis. Website: http://www.tropicos.org [accessed: 25 May 2019].

Turland N.J., Wiersema J.H., Barrie F.R., Greuter W., Hawksworth D.L., Herendeen P.S., Knapp S., Kusber W.-H., Li D.-Z., Marhold K., May T.W., McNeill J., Monro A.M., Prado J., Price M.J. \& Smith G.F. 2018. International Code of Nomenclature for algae, fungi, and plants (Shenzhen Code). Regnum Vegetabile 159. https://doi.org/10.12705/code.2018 